\title{
外傷性耳小骨連鎖異常症例について
}

\author{
川田一美・㴰本勲・㩊福焂 \\ 川出 愽彦・森本 高弘・大塚 一男*
}

\section{Ossicular Chain Derangement Due to Head Trauma}

\author{
Kazumi Yamada, Isao Takimoto, Shigeru Inafuku, \\ Hirohiko Kawade and Takahiro Morimoto \\ (Aichi Medical University) \\ Ichio Inuzuka \\ (Fukuroi City Hospital)
}

Five patients with conductive hearing loss due to head trauma sustained in traffic accidents were treated surgically. Dislocation or disappearance of the ossicle was the main cause of the conductive loss. Two patients with facial palsy showed gradual improvement without facial canal decompression. Good hearing improvement was noted in 4.

Patients with a large air-bone gap require middle ear surgery, since good hearing: recovery can be obtained by reconstruction of the ossicular chain.

Key words: traffic accident, conductive hearing loss, ossicular chain derangement

\section{はじめに}

最近の交通事故の增加とともに，その頭部外 㑺後遺症と思われる難聴，耳鳴，めまいなどを 主訴に耳舅科外来を受診する腎者は少なくな い. 䧼聴例のうち特に鼓膜に大きな病的所見が 見られないにもかかわらず，純音恥力検䍒で気 骨導差の大きな症例に将に遭遇することがあ る。このような場合多くは耳小骨連鎖の離断が 疑わ机るが，近年普及したチンパノメトリーは その診断に有用ではあるが必ずしも連鎖障㫪が 診断されうる訳でない。試験的敁室開放術では じめて病変が確認されること屯ある.

今回交通事故後の難聴例で，手術的に病変の
確認できた 5 例を経騟したのでその診断と治療 について報告する。

\section{症例}

詔和55年から60年までの 6 年間に当教空で経 験した交通事故後の難㯖例のうち, 気骨導差の 大きい 5 例で, 症例の概略は表 1 亿示すように 全て若者であった。事故当将の詳しい状沉に関 しては，全例他医からの紹介でああり，また意 識障害など伴った例む含まれるので不明な点む あった。

以下各症例について簡単な病歴とと屯に乎術 所見および経過について述べる。 
初 診：昭和55年 9 月 1 日

主 訴: 左難聴.

家族歴・既往歴：特になし.

現病歴：昭和55年 1 月22日交通事故で頭蓋骨 骨折の䛦断のもとに某病院に 1 力月入院. 事故 後 5 日間左耳より䯣液漏があり，1週間後に左 難聴之耳鳴に気付く屯10日間絶対安静であっ た。 2 月上旬に近医耳鼻科で，難聴はあるが手 術する程でないといわ机て放置していたが，そ の後再受診時に難聴の進行を指摘されて当科へ 紹介された。

初診時所見之経過：左上鼓室は拡大宿凹し上
皮化していた。オージオグラムは図 1 のようで あった，骨導は中高音域で若干の域值上昇が認 められた。チンパノメトリーは，ピークの高い C型を示した.

同年 9 月24日に手術を行った。骨部外耳道 1 $\sim 3$ 時に骨折があり, 約 $8 \mathrm{~mm}$ の深さで骨折片が 内宿癒着していた。鼓膜手前の外耳道に小円形 の骨欠損があり乳突粘膜が透見された。ツチ骨 骨頭は欠損し，キヌタ骨は見当らず。アブミ骨 は瘏痕組織で鼓膜と瘾着していたので豩離し て，耳珠軟骨をコルメラとしてアブミ骨頭にの せて鼓膜を元に戻した。 術後聴力の改善は低音

表 I 事故直後の状況

\begin{tabular}{|c|c|c|c|c|c|c|c|c|}
\hline \multicolumn{2}{|c|}{ 症 例 } & 年龄·性 & 難聴 & 事故直後の診断 & 耳出血 & 耳鳴 & めまい & $\begin{array}{l}\text { 顔神 } \\
\text { 祵僧 }\end{array}$ \\
\hline 1 & & 18歳早 & 左 & 頭蓋骨骨折 & + & + & $?$ & - \\
\hline 2 & & 19歳 今。 & 左 & $\begin{array}{l}\text { semicoma } \\
\text { brain contusion }\end{array}$ & $?$ & $\begin{array}{l}\text { 轫 } 8 \\
+\end{array}$ & - & - \\
\hline 3 & & 18歳 今 & 左 & $\begin{array}{l}\text { 意 識 障 害 } \\
\text { 右側頭骨骨折 }\end{array}$ & + & $\begin{array}{l}\text { 時保 } \\
+\end{array}$ & - & - \\
\hline 4 & & 20歳 $\hat{~}$ & 左 & 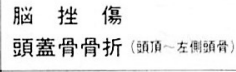 & + & - & + & + \\
\hline 5 & & 26歳古 & 左 & 左側頭部打撲 & + & + & - & + \\
\hline
\end{tabular}

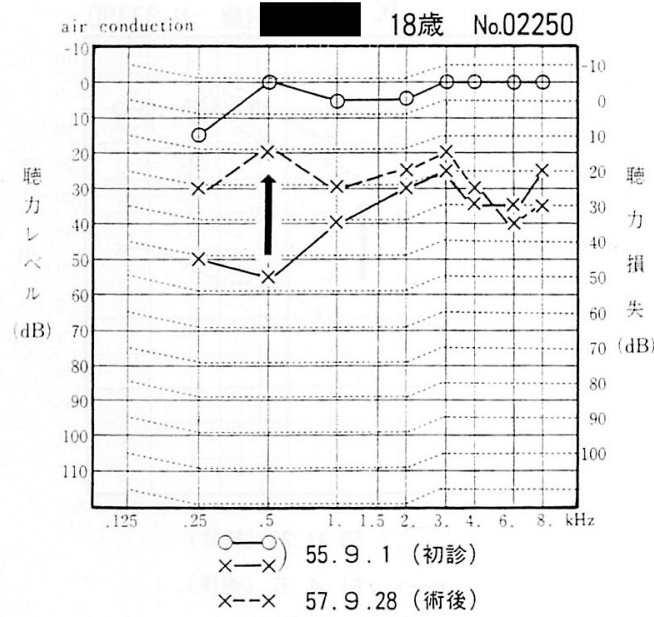

図 I 症例 1

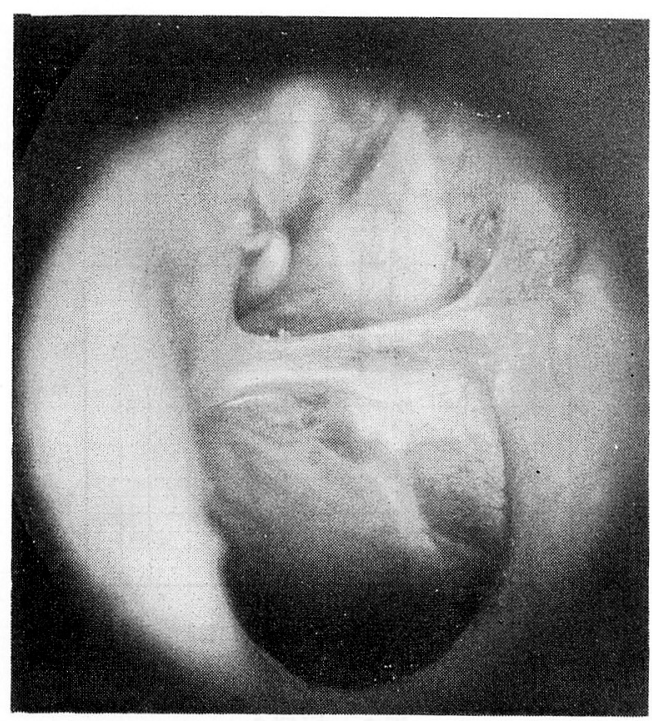

図 2 
域で得られた（図1）。

術後の鼓膜所見は図 2 のごとく，術前と同様 に上鼓室の拡大宿以を呈している.

<症例 2>

19歳令

初 診：昭和56年 3 月 19 日

主 訴：左難聴.

家族歴：特になし。

既往歴：15歳㭙口蓋扁桃摘出術.

現病歴：招和56年 1 月29日交通事故。某病院 入院侍 semicoma で C Tなどから脸挫傷, 頭 蓋底且折，一顎骨折之診断された。意識が㞍っ てから左難聴を自覚し，近医耳鼻科を受部し鹳 聴改善の希望で紹介にて当科を受診.

初彰侍所見と経過：鼓膜所見はほぼ正常であ ったが，拡大耳鏡下で可動性は良すぎる位であ った。オージオグラムは図 3 のでとくであり， チンパノメトリーは $A_{D}$ 型を示した。

同年 4 月 20 日に手術を行った。外耳道後壁 1 時の位置に骨折線が見られ，キヌタ骨関節乫起 は，はずれてねじれた形で前方へ転位してい た. Tympanic scute は陷入してキヌタ骨と 癒合していたのでキヌタ骨長脚を切除し，ツチ 骨柄とアブミ骨頭を stainless wire にて璉鎖 形成した。術後低音域で著明な聴力改善を得た (図 3 ).

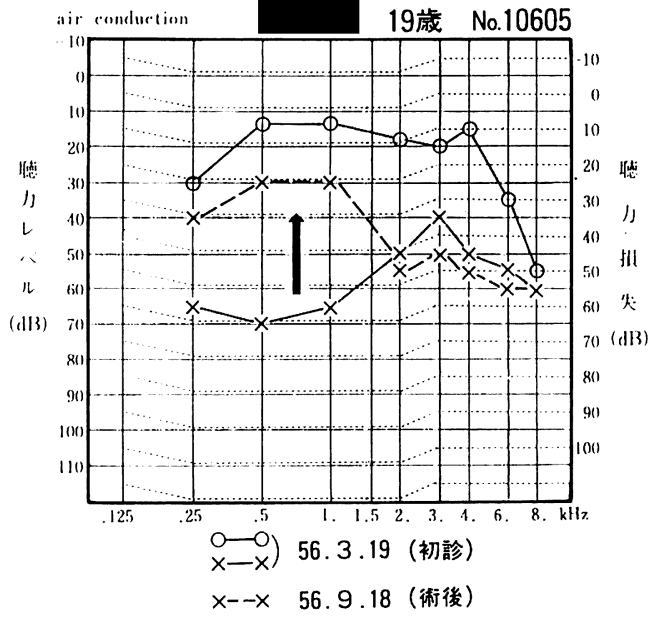

図 3 症例 2

\section{$<$ 症例 $3>18$ 歳令}

初診：炤和58年11月25日

主 訴：左難聴。

家族歴：母が糖尿病，父が胃潰瘍.

既往歴：特になし。

現病歴：昭和 57 年 5 月 17 日オートバイで事. 故. 左側頭骨骨折と左耳出血ll，意識障害があっ た。約 4 力月某病院入院中に左難聴を自覚し以 後難媤の進行はなく, 恥力改善目的で紹介にて 受診，当日入院した。

初診時所見と経過：左豉膜は上鼓室拡大し， オージオグラムは図4 のでとくであり，チンパ ノメトリーは $\mathrm{As}_{\mathrm{s}}$ 型であった。

11月28日手術を行った。 Tympanic scute は 火損し，ッチ骨とアブミ骨は良好なるもキヌタ 骨は見当らなかった。側頭骨片を加工し中央に 穴をあけアブミ骨頭にのせた。術後全周波数に 著明な憙力改善を見た（図4）.

$<$ 症例 $4>$

20 歳余

初 診：炤和59年 7 月 24 日

主 诉: 左難聴.

家族歷・既往歴：特になし。

現病歴：炤和59年 4 月27日，高速道路走行中 に車が転倒し助手席から車外へ放り出された。 意識消失, 左耳出血があって某病院に入院. 左

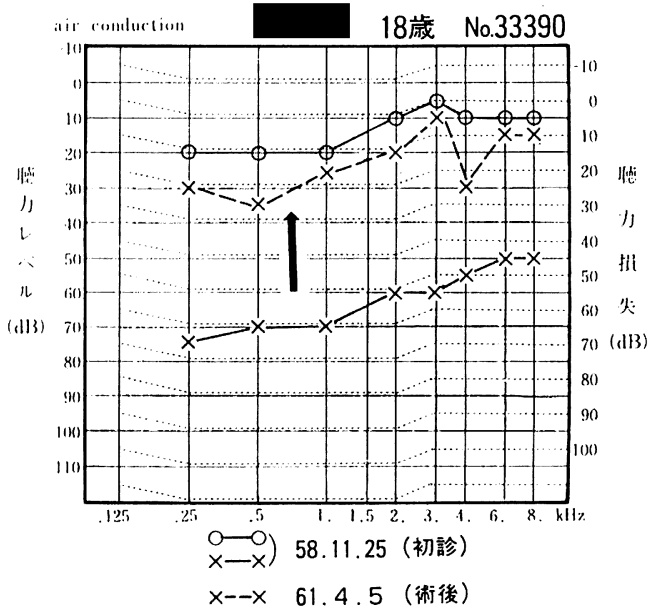

図 4 症例 3 


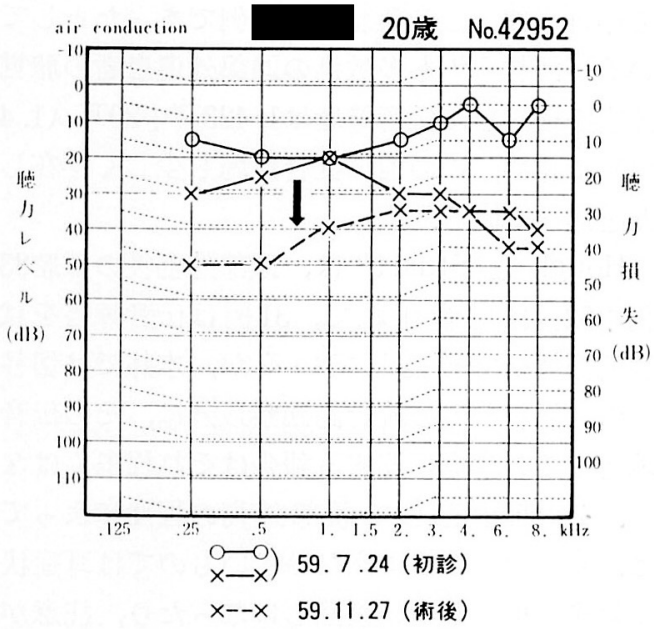

図 5 症例 4

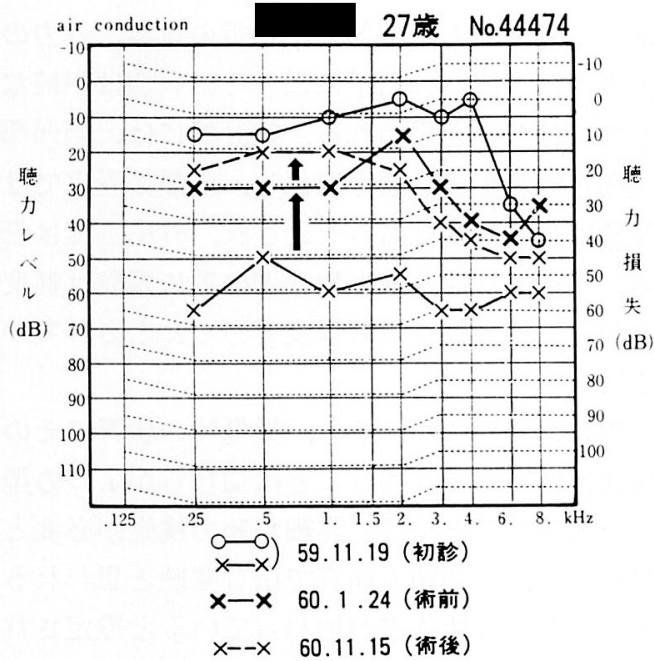

図 6 症例 5
難聴，左顔面神経麻盘に気付くも磨痺は徐々に 回復してきた。 6 月上旬に左耳漏が出現し，手 術目的にて当科へ紹介された.

初診時所見亡経過：症例 1 上同様に上鼓室拡 大陷凹と肉芽の増生を認め，オージオグラムは 図 5 のごとくであった。チンパノメトリーは幅 の広いA型を示した。顔面神経麻瘏は40点評価 で12点であった。

同年 8 月 29 日手術老行った。外耳道深部 3 〜 4 時に骨折あり。上鼓室，中鼓室に肉芽が充満 し，ツチ骨頭とキヌタ骨は欠損しアブミ骨は肉 芽に被われる屯可動性は認められた。顔面神経 は水平部で数mmの骨壁欠損があったが，骨折線

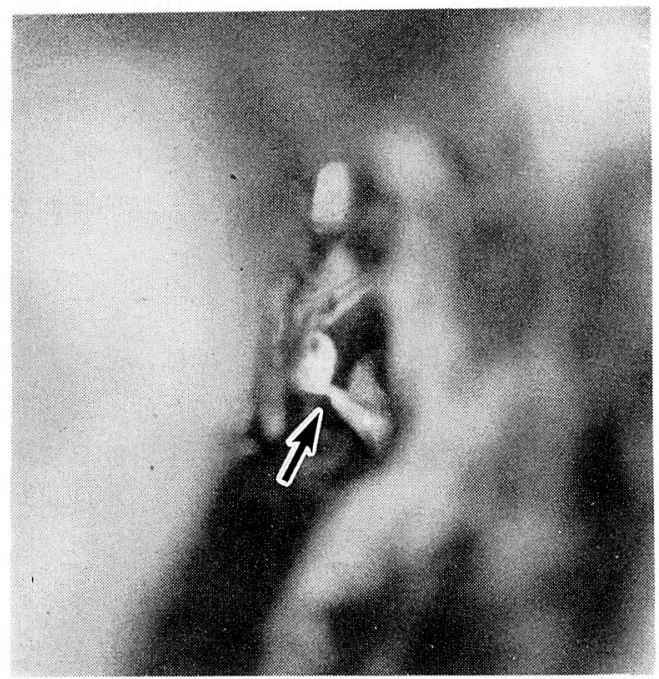

図 7 矢印はキヌタ・アブミ骨間線維性連鎖

表 2 手術所晃

\begin{tabular}{|c|c|c|c|c|c|c|}
\hline \multirow[t]{2}{*}{ 症例 } & \multirow{2}{*}{ 鼓 } & \multirow{2}{*}{ 外 } & 耳 & \multicolumn{2}{|c|}{ 小 骨 } & \multirow{2}{*}{ 顔面神経管 } \\
\hline & & & ツ 千 & キヌタ & アプミ & \\
\hline 1 & 上鼓室内陥拡大 & $\begin{array}{l}1 \sim 3 \text { 時骨折 し } \\
\text { 骨折片内陥瘾着 }\end{array}$ & 骨頭欠損 & 欠 損 & 良 & 良 \\
\hline 2 & ほぼ正常 & 後壁 1 時に骨折線 & 良 & 前方へ変位 & 良 & 良 \\
\hline 3 & 上鼓室やや拡大 & $\begin{array}{l}\text { tympanic scute } \\
\text { 欠損 }\end{array}$ & 良 & 欠 損 & 良 & 良 \\
\hline 4 & 上鼓室肉芽充満 & 3〜 4 時に骨折線 & 骨頭欠損 & 欠損 & 良 か & $\begin{array}{l}\text { 水平部欠損 } \\
\text { (先天性) }\end{array}$ \\
\hline 5 & ほほ正常 & 3〜 4 時の骨脆弱 & 良 & $\begin{array}{l}\text { 長版先端欠 } \\
\text { 損し結合绩 }\end{array}$ & 骨頭変形 & 良 か \\
\hline
\end{tabular}


と神経管との関係はなく，外傷によるむのより 先天性に火損していたもの之推定した。顔面神 経麻脾は出血と耳小骨転位などの刺激により生 じたものと推定した。術後 3 力月で顔面神経森 瘏は40点評価で36点と改善した。聴力はアブミ 骨頭に皮下結合織をのせて僛頭筋膜で婛膜形成 を行ったが，改善は得られなかった（図 5 ).

\section{$<$ 症例 $5>$}

36歳令

初 診：昭和59年11月19日

主 訴：左難聴。

家族歴・既往歴：特になし.

現病歴：昭和 59 年 7 月 25 日車が衝突し, 助手 席の人の頭が左側頭部に当って, 左耳出血あ り．27日に左顔面神経麻痺に気付いた。左耳出 血は 1 週間続き，左難聴むあり。10月に某病院 受診し，紹介にて当科を受診.

初診時所見と経過：鼓膜はほぼ正常. 初診時 のオージオグラムは図 6 亿示すごとくで, チン パノメトリーは $A_{\mathrm{D}}$ 型であった．左顔面神経麻 痺は40点評価 24 点であった。

本人の都合で手術を 2 力月後に行うことにした が，再受診時（60年 1 月 24 日）には，全周波数 において聴力の著明な改善を認めた。しかし病 変の確認と本人の希望ああって，1月28日に手 術を行った. 外耳道後壁 4 時あたりの骨は骨折 があったと推定されるように脆弱であった。 キ ヌタ骨長脚先端は丸くなり，変形したアブミ骨 頭と結合織で連鎖を形成していた（図 7 )。乙 の部の補強の意味で索状物をとり囲むように皮 下結合織を当てて, 恥力の改善を得た（図6).

以上 5 症例の手術所見は表 2 にまとめてあ る.

\section{考按}

頭部外賃による聴力障害については，既に幾 多の基礎的臨床的研究がなされている.

切替ら ${ }^{1)}$ は頭部外仵後遺症として聴覚障害を 主訴として来院した患者78名について種々の角 度からその障㕩部位を検討し, 中耳, 内耳, 後 迷路のそれぞれの病変の他に，乙の三者の組み 合せによって 7 つ型に分類している，そのう
ち中耳単独（伝音難聴）は 4 例であったとして いる. 河村 ${ }^{2)}$ 屯多数例の頭部外傷患者の聴覚 障害を検討し，伝音難聴は1,423耳中20耳（1.4 \%)に認め，この他に混合難聴屯少しく存在し たと述べている。

Hough と Stuart ${ }^{3)}$ は, 頭部外傷後の難聴83 例中52例は感音難聴で，31例は伝音障害を試 験的開放術で確認しているが，本邦では切替 $ら^{11}$ ， 河村ら ${ }^{3)}$ の統計的観察以外に，その伝音 障害やその治療に関する報告はそれ程多くはな い. その理由として頭部外傷の程度によって は，致命的になるようなひどいものでは耳症状 に対する検索がつい後回しになったり，注意が 向けられないととああるのかむしれない.

ところで頭部外傷後の難聴について，頭部に 加わる外盼の方向や部位, 罠折の有無, 外力の 大きさなど種々の因子によりその病態は単純な あのではないと思われる，統計的には，側頭部 受賃と難聴が最も強く関係し, 前額部受傷では 難聴は最む軽度であったとされ，外傷㓢では転 落, 墜落, 打攩, 飛来物などの順に難聴は軽度 となり交通事故に最も軽度であったとされてい る $^{2)}$.

難聴の種類について屯，受傷時の状沉でその 病態は種々おこりうるととは切替らが 7 つ型 に分類したでとくで, 詳細な聴力検査が必要と 思われる．純音聴力検查で伝音難聴と思われる あのにあ内耳性障害が加わっていると推定され る症例屯報告"1)されている。

今回の 5 例でむ純䊉に伝音難聴という訳でな く，全例に高音域にわずかの骨導域值の上昇が 見られ，症例 5 では対側耳に屯高音域に同様の 域值上昇があった，受傷時の詳細な状況は不明 な点もあるが，手術により 5 例其に何らかの患 耳の骨折が認められたことから患側の側頭骨に 強力な外力が働いたととは間跶いない。

Hough と Stuart ${ }^{3)}$ は，頭部外傷後の中耳損 傷の症状を “the traumatic conductive triad” として (1) loss of hearing, (2) bleeding from the ear, (3) unconsciousness を挙げて 
いる. この triad は比較的頻度が高いもので あるが，その他の臨床所見屯参考にして総合的 に彰断する必要があろう。今回の 5 例であ全例 でこの triad を備えていた訳ではなかった。

現在では，鼓膜穿孔がなく気骨導差の大きな 症例にはチンパノメトリーが有力な検查法とし て多用されている。しかしながら耳小骨連鎖離 断が必ずしも $A_{D}$ 型を示すとは限らないので, 気骨導差の原因不明ないし連鎖離断が疑打れた ら，また本人の同意が得られれば積極的に試験 的鼓室開放術を行うことが必要と思われる，連 鎖の障害を再建することにより術後の恥力改善 が著しいことは今回の症例でも明らかである。 症例 5 のような経過中に気骨導差が小さくなっ た場合む，その原因が不完全連鎖を帅成したた めと納得できる。このような症例は稀ではあろ うが，手術的に確認された例が報告尔4) されて いる。

一般に外賃後の耳小骨連鎖障邫部位は，多く はキヌタ・アブミ関節に認められることは諸家 の報告でも一致しており，今回の 5 例でも全例 に認められた。またツチ骨，キヌタ骨の久損や 消失む稀ではあるが報告 ${ }^{3)}$ されており, 今回の 5 例中 3 例にあキヌタ, 骨の消失が認めれた。乙 れらの例では開放された術野には認められず, 症例 4 の炎症併発による以外にはその理由につ いては不明であった。

速鎖の再建には，一般に局所の炎症所見もほ とんごないととが多いので，手頃なコルメラ材 料（骨片，軟骨など）を用いるか，人丁耳小肖 の使用は好適之思わ机る。 またその手術特期に ついては，患者の全身状態や希望に応じて行う ことで, 特に早期に行うことが必要とは思わな いが, 症例 4 のように他科での比較的長期管理 必要な例では炎症を併発してからの手術であっ たため，手術侍期についてはむつかしい面があ った。
難恥のほかに顔面神経麻痺を合例するような 例では，骨折による損傷など考慮して早期に乎 術を行う必要があろう ${ }^{5)}$ が，今回の 2 例では当 科受診までに症例 5 ではかなり回復を示してい たし，症例 4 では先天性の欠損に炎症や出血な どの病変が加わって麻瘼が発症したと思われる が，術後 3 力月でほぼ治癒した。

\section{まとめ}

父通事故による頭部外傷後の伝音難埴例に手 術を行い，その耳小霄病変を中心に報告した. 今後交通事故に限らず頭部外鹪後に難聴を主訴 とする例において気骨導差の見られる場合は聴 力改善が大いに望めるので, 積極的に手術を行 う必要があると思われた。

本論文の要旨は第45回日耳鼻東海地方部会連合講演 会および第14回日本臨床耳科学会において口演した.

\section{参考文献}

1) 切替一郎, 杉浦 茂, 江口公昭, 他: 頭部外㩐後 遗症における聴覚障害の臨床的考察. 日耳鼻 68 : 743 750, 1965.

2 ) 河村進市，菅原義春，鴻 博義：頭部外傷による 聴覚障害と学災補償. 災害医学 $7: 129 \sim 134$, 1964.

3) Hough JVD and Stuart WD : Middle ear injuries in skull trauma. Laryngoscope 78 : 899〜937, 1968.

4）新見誠司, 岡本牧人, 設楽哲也：外傷性伝音難聴 について. 臨床耳科 10:102 103，1983.

5 ）牧島和見, 渡辺 厷, 渡辺 普: 側頭骨骨折に上 る伝音性難聴と顔面神経麻軲の手術. 日耳鼻 84 $: 1 \sim 5,1981$.

(別刷請求先：山田一美

T480-11 装知県悉知郡長久手町大字岩作字倠又 21 愛知医科大学耳鼻咽喉科学教室 